\title{
The Effectiveness of Ice Massage Therapy for Low Back Pain Patients
}

\author{
Anugrahani Tiara Rizki ${ }^{1}$, Naufal Yudi Pratama ${ }^{2}$, Gustiana Mega Anggita $^{3}$ \\ \{mega.anggita@mail.unnes.ac.id $\left.{ }^{3}\right\}$ \\ Universitas Negeri Semarang, Semarang, Indonesia ${ }^{1,2,3}$
}

\begin{abstract}
Low back pain was suffered by almost $90 \%$ of human during their lives, especially in people who have risk factors for low back pain. Low back pain is one of the musculoskeletal causes due to poor activity and the emergence of aches, rheumatic pain. One of the non-pharmacological therapies that can be used to reduce low back pain is cold therapy, namely cold therapy. Cold therapy (cold therapy) is a physiotherapy that is widely used in sports injuries. Physiological effects of cold therapy include vasoconstriction of arterioles and venules, decreased sensitivity of free nerve endings and decreased metabolic rate of cells, resulting in decreased demand for cell oxygen. This whole process can reduce the swelling process, reduce pain, reduce muscle spasm and the risk of cell death. Cold therapy that is widely used in the form of ice massages, ice packs, cold baths / water immersion and vapocoolant sprays. The use of cold therapy must be carried out with a proper procedure considering there are several therapeutic risks such as irritation, hypothermia, frost bite. This therapy is contraindicated in several clinical disorders, including Raynaud's syndrome, cyroglobunemia, paraxoxymal hemaglobinuria, vasculitis and sensory neurological disorders such as diabetes mellitus. The purpose of this article is to determine the effect of giving ice massage on changes in pain intensity in people with low back pain.
\end{abstract}

Keywords: low back pain, ice massage, cold therapy.

\section{Introduction}

In the United States, more than $80 \%$ of complaints are in the second position after headache, namely Low back pain. Pain that is most often felt in the back area, especially the lower part, is called Low Back Pain. Low back pain can be local pain or radicular pain or both (Mahadewa \& Maliawan, 2009). This pain is felt between the angle of the lower ribs and the fold of the lower buttocks, namely in the lumbar or lumbar-sacral region and is often accompanied by radiating pain to the legs and feet. According to Sigamani (2007) pain is an unpleasant sensory and emotional experience that can be accompanied by acute or potential tissue damage.

In fact Low Back Pain is the third common cause of disability in the United States (MacCann, 2003). LBP is the second cause of lost work time, the fifth reason for hospitalization, and the third reason for surgical procedures. Losses due to loss of productivity due to low back pain are around 28 million US dollars per year in the United States (Wheeler, 2009). According to Bull and Archard (2007) in England, low back pain is the most frequent medical complaint after the common cold. 
Epidemiological data regarding low back pain in Indonesia does not yet exist. However, it is estimated that $40 \%$ of Central Java population aged 65 years have suffered from Low Back Pain and the prevalence in men is $18.2 \%$ and $13.6 \%$ in women (Mahadewa \& Maliawan, 2009). From the results of a national study conducted in 14 cities in Indonesia by the Pain group of the Indonesian Neurologist Association / PERDOSSI in Purba and Susilawaty (2008) found $18.13 \%$ of low back pain sufferers with an average VAS value (Visual Analog Scale) of $5.46 \pm 2.56$, which means moderate to severe pain.

Low back pain that is felt can certainly be a problem if it interferes with daily activities. For workers this pain will certainly interfere with their work and reduce their productivity. As a result of the impact that can be felt by sufferers of Low Back Pain, it is necessary to make efforts to reduce pain. Reducing pain can be done using pharmacological therapy or using non-pharmacological therapy, that is, without using drugs. One form of non-pharmacological therapy is physiotherapy in the form of cold therapy (cryotherapy), which is a simple and effective procedure to reduce muscle spasm so as to reduce pain (Sigamani, 2007). The cold therapy method that can be used is ice massage. Ice massage is the act of massaging using ice on the affected area. This action is a simple thing that can be done to relieve pain. Giving ice massage is carried out for 5 to 10 minutes. The purpose of this article was to determine the effect of ice massage cold therapy on changes in pain intensity in people with low back pain.

\section{Method}

A total of 11 articles were used as data in this review article. The data used in this article are secondary data. Secondary data were obtained from articles published in the last 20 years with the topic of the effect of ice massage on people with low back pain. These articles were obtained from various library sources such as Google Scholar, Springerlink, Reseacrhgate, Emerald and so on. The analysis used in this literature review includes four steps that must be carried out sequentially to provide acceptable answers to the research question. 1) The stages of searching and collecting material about the effect of ice massage on people with low back pain; 2) Stage of reduction and coding, screening and classification of material according to the topic of discussion; 3) The analysis and synthesis stage, examining and digging up detailed information about the material obtained; 4) The conclusions presentation stage is the final stage of the article review process and to state the novelty of the research. The review process can be seen in Figure 1. 


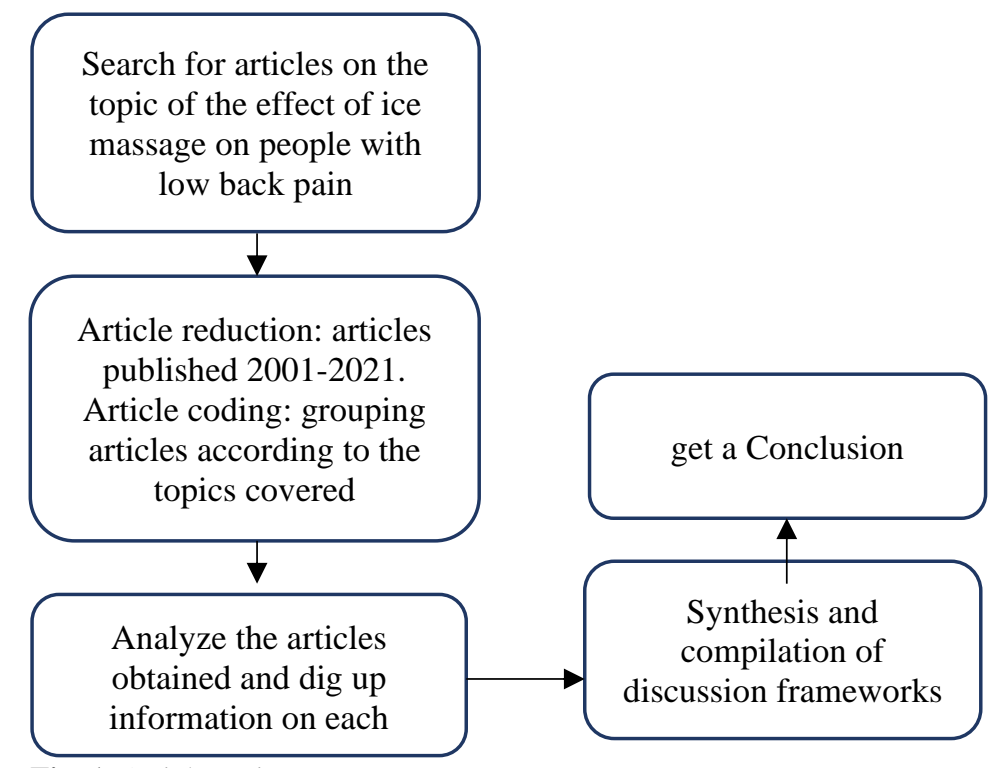

Fig. 1. Article review process.

\section{Result and Discussion}

The review process carried out to select articles according to the criteria resulted in several articles that became references to the main topic, namely the effect of ice massage on sufferers of low back pain. Below is a tabulation of data based on the results of the data reduction that has been done by the researcher.

Table 1. Data tabulation of articles with the theme of ice massage and low back pain.

\begin{tabular}{|c|c|c|c|}
\hline No & Title & $\begin{array}{c}\text { Year of } \\
\text { Publicationt }\end{array}$ & Source \\
\hline 1 & $\begin{array}{l}\text { Pengaruh Back Exercise pada Nyeri Punggung } \\
\text { Bawah. }\end{array}$ & 2009 & $\begin{array}{l}\text { Tesis Magister Kedokteran } \\
\text { Keluarga Program Studi } \\
\text { Pendidikan Profesi Kesehatan } \\
\text { pada Universitas Sebelas Maret } \\
\text { Surakarta. }\end{array}$ \\
\hline 2 & $\begin{array}{l}\text { Pengaruh terapi dingin ice massage terhadap } \\
\text { perubahan intensitas nyeri pada penderita Low } \\
\text { back pain. }\end{array}$ & 2012 & $\begin{array}{l}\text { Jurnal Ners Indonesia, Vol. 2, No. } \\
2\end{array}$ \\
\hline 3 & Latihan pada penderita nyeri punggung bawah. & 2005 & Medika jwalita edisi III, 8-9. \\
\hline 4 & $\begin{array}{l}\text { Simple guide nyeri punggung } \\
\text { Efektifitas Terapi Ice Massage dan Back }\end{array}$ & 2007 & Jakarta: Erlangga. \\
\hline 5 & $\begin{array}{l}\text { Massage Terhadap Perubahan Intensitas Nyeri } \\
\text { pada Pasien Low Back Pain di Rumah Sakit } \\
\text { Grandmed Lubuk Pakam Tahun } 2020 .\end{array}$ & 2020 & $\begin{array}{l}\text { Jurnal Keperawatan dan } \\
\text { Fisioterapi (JKF) }\end{array}$ \\
\hline 6 & Low back pain : definition and classification. & 2003 & America pharmacist association. \\
\hline 7. & $\begin{array}{l}\text { Relieving labor pain by ice massage of the } \\
\text { hand. }\end{array}$ & 2008 & Journal \\
\hline
\end{tabular}


Penambahan Ice Massage pada Intervensi

8. Back Exercise Mckenzie Lebih Baik

. Meningkatkan Fungsional Low Back Pain pada Pengerajin Batik Di Kecamatan Pandak.

9. Ice massage for reduction of labor pain.

Pengaruh William's Flexion Exercise Terhadap

Mobilitas Lumbal Dan Aktivitas Fungsional

10. Pada Pasien-Pasien Dengan Nyeri Punggung Bawah (NPB) Mekanik Subakut Dan Kronis, Pengaruh Terapi Panas, Dingin, dan Panas-

11. Dingin Terhadap Intensitas Nyeri pada Pasien

1. Low Back Pain (LBP) di Rumah Sakit Umum Daerah Dr. Pirngadi Medan.
Program Studi Fisioterapi Sekolah Tinggi Ilmu Kesehatan ‘Aisyah Yogyakarta
Journal of midwifery \& women's health

Program Studi Rehabilitasi Medik Fakultas Kedokteran Universitas Diponegoro. Semarang

Journal

Studies on the effect of ice massage on people with low back pain have been discussed in various scientific papers such as books and articles in scientific journals. Along with the development of the era, ice massage is studied more deeply to be able to provide benefits to sports players in the field of sports recovery.

\subsection{Low Back Pain}

Low Back Pain (LBP) is a common complaint. LBP, then, is pain that is felt in the lower back area, it can be local pain or radicular pain or both (Mahadewa \& Maliawan, 2009). This pain is felt between the angle of the lower ribs and the fold of the lower buttocks, namely in the lumbar or lumbar-sacral region and is often accompanied by radiating pain to the legs and feet. According to Sigamani (2007) pain is an unpleasant sensory and emotional experience that can be accompanied by acute or potential tissue damage.

Signs and symptoms of LBP are the discovery of muscle pain known as myogenic pain, which is pain that is not appropriate with the distribution of nerves and dermatomes with frequent exaggerated reactions. The pain is characterized by tenderness in the area (trigger point), loss of range of motion (loss of range motion), low back muscle spasm. The presence of muscle spasm in the lumbosacral region, imbalance of the stabilizer and trunk fixators, limited lumbosacral mobility, resulting in decreased functional activity. complaints will disappear when the lumbosacral muscle group is stretched (Pramita, 2014).

The incidence of Low Back Pain (LBP) is almost the same in all populations in both developed and developing countries (Shocker, 2018). The incidence of LBP in the United States is approximately 5\% in adults. Approximately $60 \%-80 \%$ of individuals have experienced back pain in their life. The peak age of LBP sufferers is at the age of 45-60 years. In adult patients, LBP can interfere with daily activities in $40 \%$ of patients, and sleep disturbances in $20 \%$ of patients. Most of the $75 \%$ of sufferers will seek medical help, and $25 \%$ of them need to be hospitalized for further evaluation (Widiyaningsih, 2015).

According to Porth (2005) low back pain attacks women and men as much and attacks usually occur at the age of 30-50 years. Low back pain can also occur in the elderly, intervebral discs will change in character as they get older. The intervebral disc will become dense and regular fibrocartilage. Disc degeneration is a common cause of back pain (Smeltzer $\&$ Bare, 2001). The lower lumbar disc suffers from the most severe mechanical stress and the heaviest degenerative changes. 
One of the factors causing mechanical low back pain is physical factors related to work such as sitting and driving, sitting or standing for hours (static work body position), vibration, lifting, carrying loads, bending and rotating the body (Mahadeva \& Maliawan, 2009). It is suspected that the cause of housewives experiencing low back pain is due to doing housework such as washing, sweeping, cooking and ironing regularly and usually requires body movements such as lifting objects, bending or turning the body so that it has the potential to experience low back pain. Many housewives do the habit of washing clothes with a bending motion, or picking up objects with a bending motion. This method can put stress or mechanical stress on the lumbar which can eventually lead to lower back pain. Based on the results of this study, it can be concluded that not only workers such as drivers, farmers or construction workers can experience low back pain but housewives are also at risk of experiencing low back pain.

Based on several theories and research on the effects of low back pain, it is necessary to make efforts to reduce pain. Reducing pain can be done using pharmacological therapy or using non-pharmacological therapy. The cryotherapy method that can be used is ice massage. Handling using ice massage is seen from the process of trauma or injury to the soft tissue. Application using ice massage can provide changes to the skin, subcutaneous tissue, intramuscular and temperature in the joints (Cheung et al, 2013).

\subsection{Ice Massage}

Physiotherapy in the case of Low Back Pain plays an important role in reducing pain complaints and improving functionality so that patients can return to their activities. To overcome the problem of Low Back Pain, physiotherapy modalities can be used such as: Heat therapy, including Hot packs, Short Wave Diathermy (SWD), Micro Wave Diathermy (MWD), Infra Red (IR). Cold therapy includes cold compresses and ice massages. Electrical therapy includes Transcutaneous Electrical Nerve Stimulation (TENS), interference (IF), dyadinamis. Manipulation therapy, stretching, massage.

The physiotherapy modality used in this study was ice massage. Ice massage is the act of massaging using ice on the affected area. This action is a simple thing that can be done to relieve pain. Giving ice massage is carried out for 5 to 10 minutes (Erika, et al 2012). (Dachlan, 2009).

Ice massage is a method that can be used to help reduce tissue damage and prevent inflammation of the muscles, tendons and ligaments. Ice massage is very good for reducing pain and discomfort caused by strains, odes. The cold sensation you feel from ice will reduce the occurrence of inflammatory processes in the tissue and reduce the risk of odeme. The effect of ice massage can provide a relaxing effect that has a sedative effect on muscle tissue. Physiotherapy helps accelerate the healing process, when metabolism decreases when given ice massage, and the blood will return to bring nutrition and will accelerate the healing process. Ice massage will reduce the occurrence of swelling and maintain blood circulation (Rakasiwi, 2013)

In several studies, the addition of ice massage is better at increasing functional ability in Low Back Pain because ice massage has physiological effects caused by this cold therapy, including vasoconstriction, relaxing muscles that experience spasm, reducing pain, slowing pain impulse travel and increasing the pain threshold. , and provide a local anesthetic effect. It is estimated that $90 \%$ of Low Back Pain is based on mechanical factors and about $60 \%-70 \%$ of the causes are strains. This strain is the tension in the muscles as a result of wrong posture and muscle strength. Pain that is felt is local without spreading. The provision of cold therapy 
in the form of ice massage can relax the muscles in spasm and provide a local anesthetic effect so that it can be used as an alternative therapy to reduce pain. In accordance with the complaints felt by respondents with Low Back Pain, respondents felt local pain and sore muscles around the lower back (Someren, 2005).

The effect of ice massage is also stated by Hajiamini, et al (2012) in their research entitled "Comparing the effects of ice massage and acupressure on labor pain reduction". It is concluded that Ice massage is more effective than acupressure in reducing pain, Ice massage has the advantage of having no side effects, does not require further training and can be done in remote areas where access to medical and professional methods is limited.

\subsection{The effectiveness of ice massage therapy in low backpain patients}

The results of the study on the average pain scale in Low Back Pain patients before cold therapy (Ice Massage) found that there was an effectiveness of providing ice massage therapy on pain intensity in Low Back Pain patients. The results of the study are in accordance with research by Eva Nurlis (2012) that there is an effect of cold therapy (ice massage) on changes in pain intensity in people with low back pain. Cold compress can reduce pain in patients. Cold compresses have several advantages, including local analgesic effects, reducing inflammation, increasing the threshold for pain receptors and then reducing pain. The cold compress used to reduce pain is applied for approximately 20 minutes, because prolonged exposure to cold will cause injury to the tissue (Bimariotejo, 2015).

\section{Conclusion}

Based on the above discussion, it can be concluded that there is an effectiveness of Ice Massage therapy on changes in pain intensity in Low Back Pain sufferers.

The results of this study are expected to be used as information on ice massage therapy scientifically and can apply ice massage therapy as a safe, effective non-pharmacological therapy and to reduce pain scales.

\section{References}

[1] Dachlan, L. M. (2009). Pengaruh Back Exercise pada Nyeri Punggung Bawah. Tesis Magister Kedokteran Keluarga Program Studi Pendidikan Profesi Kesehatan pada Universitas Sebelas Maret Surakarta. Available from: http://core.ac.uk/download/pdf/12347068.pdf diakses tanggal 21 februari 2015

[2] Eva Nulis, Erika, Bayakki. (2012). Pengaruh Terapi dingin Terhadap Perubahan Intensitas Nyeri Pada Penderita Low Back Pain. Jurnal Ners Indonesia. Vol. 2 hal: 185-191. Ganong. (2010). Review of Midical Physiologi. Twenty three edition. United States: The Mc Graw-Hill Companies.

[3] Arline, V. D (2015). Penambahan Ice Massage pada Intervensi Back Exercise Mckenzie Lebih Baik Meningkatkan Fungsional Low Back Pain pada Pengerajin Batik Di Kecamatan Pandak. Program Studi Fisioterapi Sekolah Tinggi Ilmu Kesehatan 'Aisyah Yogyakarta 2015

[4] Bull, E. \& Archard, G. (2007). Simple guide nyeri punggung (Surapsari, J.). Jakarta: Erlangga. (Naskah asli dipublikasikan tahun 2005).

[5] Sunarto. (2005). Latihan pada penderita nyeri punggung bawah. Medika jwalita edisi III, 8-9. Diperoleh tanggal 19 Oktober 2009. Dari http:/ /fisioterapi.org/jurnal.php

[6] Hayati Kardina \& Tati Devi (2020). Efektifitas Terapi Ice Massage dan Back Massage Terhadap Perubahan Intensitas Nyeri pada Pasien Low Back Pain di Rumah Sakit Grandmed Lubuk Pakam 
Tahun 2020. Jurnal Keperawatan dan Fisioterapi (JKF), e-ISSN 2655-0830 Vol. 2 No. 2 Edisi November 2019 - April 2020

[7] Zanni, G. R. (2003). Low back pain : definition and classification. America pharmacist association. Diperoleh tanggal 6 Desember 2009 dari www.medscape.com/cdc-commentary

[8] Faranak S. D., et al. (2008). Relieving labor pain by ice massage of the hand. Diperoleh tanggal 6 Desember 2009. Dari http://www.sid.ir/66513880108.pdf

[9] Waters, B. L., \& Raisler, J. (2003). Ice massage for reduction of labor pain. Journal of midwifery \& women's health, 48 (5). Diperoleh tanggal 6 Desember 2009 dari www.medscape.com

[10] Kurniawan, H. (2004). Pengaruh William's Flexion Exercise Terhadap Mobilitas Lumbal Dan Aktivitas Fungsional Pada Pasien-Pasien Dengan Nyeri Punggung Bawah (NPB) Mekanik Subakut Dan Kronis, Program Studi Rehabilitasi Medik Fakultas Kedokteran Universitas Diponegoro. Semarang.

[11] Phonna, D.C. (2014).Pengaruh Terapi Panas, Dingin, dan Panas-Dingin Terhadap Intensitas Nyeri pada Pasien Low Back Pain (LBP) di Rumah Sakit Umum Daerah Dr. Pirngadi Medan. Availabel from http://repository.usu.ac.id diakses tanggal 01 January 2016 